\title{
Osteotomía subcondílea en el tratamiento de las deformidades mandibulares
}

\section{Subcondylar osteotomy in the treatment of mandibular deformites}

\author{
J. Alonso del Hoyo
}

Resumen: La corrección quirúrgica del prognatismo mediante intervenciones en las ramas ascendentes de la mandíbula, fue la opción que sustituyó a las técnicas de ostectomías que reducían el volumen mandibular o más exactamente la longitud del cuerpo bilateralmente. Se realizan osteotomías subcondíleas oblícuas por encima de la espina de Spix, preservando el paquete vásculo-nervioso que, partiendo de la escotadura sigmoidea, llegan al borde posterior de la mandíbula. Desde el año 1974 hemos empleado la técnica subcondílea oblicua (OSO) por vía intraoral en 367 casos para la corrección del prognatismo.

\section{Introducción}

La corrección quirúrgica del prognatismo mediante intervenciones en las ramas ascendentes de la mandíbula, fue la opción que sustituyó a las técnicas de ostectomías que reducían el volumen mandibular o más exactamente la longitud del cuerpo bilateralmente. Si bien desde el punto de vista estético cumplían en muchos casos un objetivo estimable, tenían inconvenientes en cuanto a su vía de abordaje (externo) y a la funcionalidad lingual: reducción del espacio para su alojamiento, manteniendo su anclaje posterior.

Las osteotomías «deslizantes» han obviado en gran parte estos inconvenientes, si bien los músculos depresores podrán a veces actuar negativamente sobre los resultados causando mordidas abiertas.

La técnica sagital de Obwegeser-Dal Pont, ${ }^{1}$ constituyó un importante avance y fue aceptada como ideal en EE.UU. primero (1963) y después en el resto del mundo.

La relativa dificultad quirúrgica de esta técnica, se veía compensada por la posibilidad de realizarse por vía intraoral, lo que permitía llevarla a cabo a cirujanos orales quienes tenía vedado el acceso por vía externa.

Anteriormente, en 1957 Hinds y Robinson, ${ }^{2}$ describieron la técnica subcondílea para retruir la mandíbula prognática.

Se realizan osteotomías subcondíleas oblicuas por encima de la espi-

Profesor Titular de Universidad. Cirugía Oral y Maxilofacial. Madrid. España

\section{Correspondencia:}

J. Alonso del Hoyo

c/ O’Donell 30

28009 Madrid, España.
Abstract: The surgical correction of prognathism by interventions in the ascending branches of the mandible was the option that substituted the "ostectomy» techniques that reduced the mandibular volume or, more exactly, the length of the body bilaterally. Subcondylar oblique osteomies are performed above Spix's spine, preserving the vascular-nervous package, that comes from the signoid notch, reaching the posterior border of the jaw. Since the year 1974, we have used the subcondyar oblique technique (SOO) intraorally in 367 cases for the correction of prognathism.

\section{Introduction}

The surgical correction of prognathism by interventions in the ascending branches of the mandible was the option that substituted the "ostectomy» techniques that reduced the mandibular volume or, more exactly, the length of the body bilaterally. Although from an esthetics point of view they fulfilled a substantial objective in many cases, they have disadvantages in regards to access route (external) and lingual functionality: reduction of the space for its lodging, maintaining its posterior anchorage.

The "sliding" osteotomies have mostly obviated these disadvantages, although the depressor muscles could sometimes act negatively on the results, causing open bites.

The sagittal technique of Obwegeser-Dal Pont, ${ }^{1}$ made up an important advance and was accepted as ideal in the U.S.A. first (1963) and later in the rest of the world.

The relative surgical difficulty of this technique is compensated by the possibility of performing it intraorally, which would make it possible for oral surgeons who could not access it externally to carry it out.

Previously, in 1957, Hinds and Robinson ${ }^{2}$ described the subcondylar technique to retrude the prognathic mandible.

Subcondylar oblique osteomies are performed above Spix's spine, preserving the vascular-nervous package, that comes from the signoid notch, reaching the posterior border of the jaw. The Caldwell's and Letterman's osteotomies (1954),3 initiated in the mandibular border and ascended towards the sigmoid notch. 
na de Spix, preservando el paquete vasculo-nervioso, que partiendo de la escotadura sigmoidea, llegan al borde posterior de la mandíbula.

Las osteotomías de Caldwell y Letterman (1954), ${ }^{3}$ se iniciaban en el borde mandibular y ascendían hasta la escotadura sigmoidea.

Ambas técnicas son descritas por sus autores con abordaje externo: preauricular y submandibular respectivamente. Ello supone una desventaja frente a la técnica sagital a la que hay que añadir la posible lesión del VII par.

Posteriormente se comenzaron a ensayar con éxito abordajes intraorales, que se mantienen hasta la fecha.

\section{Material y método}

Desde el año 1974 hemos empleado la técnica subcondílea oblicua (OSO) por vía intraoral en 367 casos para la corrección del prognatismo:

- OSO exclusivamente 98.

- OSO combinadas con otras osteotomías 270.

Desde el punto de vista de la investigación hemos de citar las dos tesis doctorales realizadas por colaboradores nuestros que reafirmaron más nuestra preferencia por la OSO.

La primera de ellas fue realizada por el Dr. F. Monje Gil en 1992 sobre la influencia de los factores extraarticulares sobre la ATM. ${ }^{4}$ La investigación se llevó a cabo en 289 ratas, de las cuales en 60 se practicó OSO bilateral. Se pudo demostrar la buena respuesta a la cirugía en la adaptación de la ATM después de un periodo de remodelación de la articulación.

En la tesis del Dr. J. Fernández Sanromán, «Influencia de la Cirugía Ortognática en la ATM», 5 se analizó la respuesta quirúrgica de la ATM, en 35 pacientes intervenidos con OSO entre los años 1990 y 1993. El estudio se llevó a cabo desde el punto de vista clínico y con distintas técnicas de imagen. Se demostró también que la fisiología articular se recuperaba favorablemente tras un periodo de adaptación paulatina.

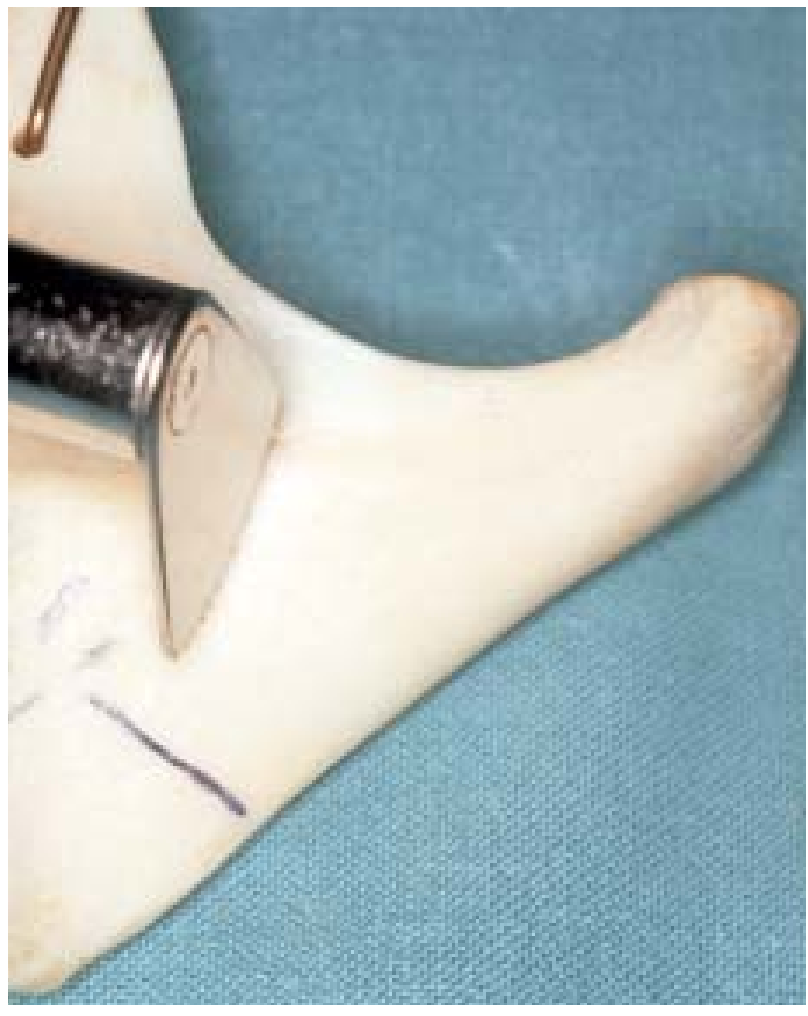

Figura 1. «Hinds modificado». Dirección de las osteotomías. Figure 1. «Modified Hinds». Direction of the osteotomies.

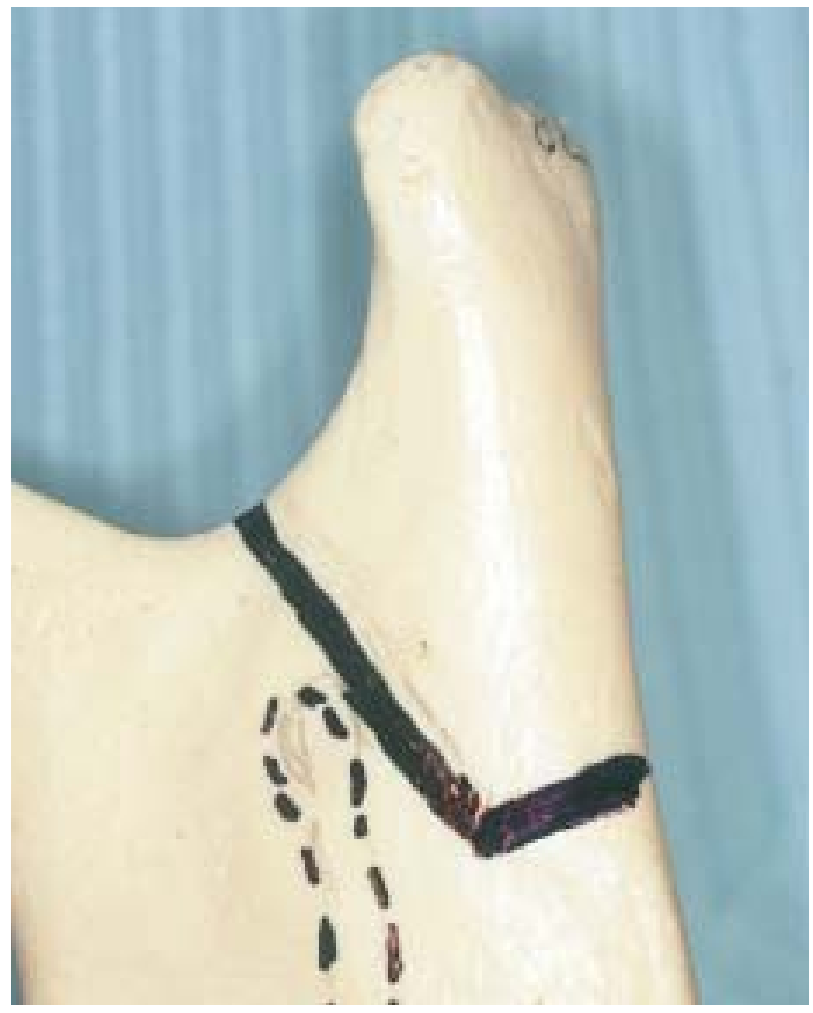

Figura 2. Trazado por encima de la espina Spix. Figure 2. Line above the Spix's spine.
Both techniques are described by their authors with external approach: perauricular and submandibulara respectively. This means a disadvantage versus the sagittal technique to which the possible injury of the auditory nerve must be added.

After, intraoral approaches were tested with success and have been maintained up to now.

\section{Material and method}

Since the year 1974, we have used the subcondyar oblique technique (SOO) intraorally in 367 cases for the correction of prognathism:

- SOO Exclusively 98.

- SOO Combined with other osteotomies 270.

From the research point of view, we must cite the two doctorate thesis performed by our collaborators that verify most our preference for the subcondylar oblique osteotomy (SOO).

The first one was done by Dr. F. Monje Gil in 1992 on the Influence of ortognathic surgery in the temporomandibular joint (TMJ). ${ }^{4}$ The investigation was carried out in 289 rats, of which 60 were done as bilateral SOO. Good response to the surgery in the adaptation of the TMJ could be demonstrated after a remodeling period of the joint.

In the thesis of Dr. J. Fernández Sanromán, «Influencia de la Cirugía Ortognática en la ATM» (Influence of Ortognathic Surgery in TMJ), 5 the surgical response of the TMJ in 35 patients operated on 
En nuestra opinión, la técnica de Hinds intraoral, es la más adecuada para la corrección del prognatismo y la empleamos desde 1974.

Nosotros en el año 1977 introdujimos una variante en la técnica de Hinds. ${ }^{6}$ Consiste en realizar la osteotomía en dos trazos: uno horizontal desde el borde posterior por encima de la espina de Spix y otro oblícuo que partiendo de la escotadura va a confluir con el primer trazo en su extremo anterior. De este modo el fragmento proximal no es triangular sino trapezoidal (Figs. 1 a 4).

La razón de esta modificación fue que con la técnica original, el fragmento mesial -que desde la escotadura sigmoidea llegaba al borde posterior mandibular- presentaba a nuestro juicio dos inconvenientes: cierta dificultad para eludir la entrada del paquete vásculo-nervios en algunos casos y además, el fragmento era muy estrecho en su extremo inferior y podía originar una necrosis distal.

El trazo horizontal de nuestra osteotomía, elimina ambas cosas.

\section{Discusión}

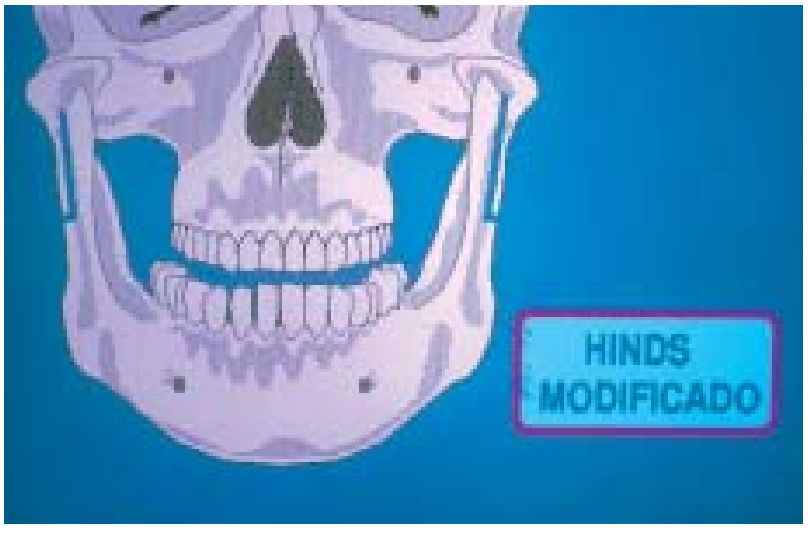

Figura 3. Esquema de osteotomía bilateral.

Figure 3. Bilateral osteotomy outline.

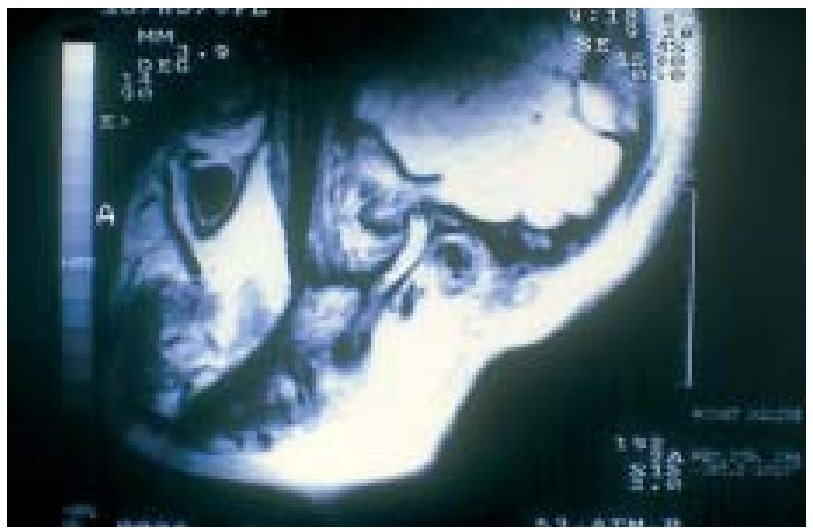

Figura 4. R.M. Control postoperatorio.

Figure 4. Postoperatory panoramic x-ray. with SOO between 1990 and 1993 was analyzed. The study was carried out from the clinical point of view and with different imaging technique. It was also demonstrated that the articular physiology recovered favorably after a slow adaptation period.

In our opinion, the intraoral Hinds technique is the most adequate for the correction of prognathism and we have used it since 1974.

In the year 1977, we introduced a variant in the Hinds technique. ${ }^{6}$ It consists in performing the osteotomy in two lines: one horizontal from the posterior border above Spix's spine and the other oblique which, leaving the notch that is going to come together with the first line in its anterior end. In this way, the proximal fragment is not triangular but rather trapezoidal. The reason for this change was that with the original technique, the mesial fragment -that aportaron las tesis citadas, teníamos la convicción de que la OSO era más beneficiosa para la función de la ATM que la técnica sagital, al permitir al cóndilo la libertad para adoptar la posición más adecuada «cómoda» dentro de la cavidad articular.

Hay otro hecho muy interesante que apoya la elección de la OSO y es que la consideración del callo de fractura no finaliza hasta transcurridos por lo menos tres meses. Quiere decir esto que durante un largo periodo postoperatorio el callo es «blando» y en cierto modo «maleable». Esto favorece que el cóndilo vaya adoptando la relación más cómoda con la cavidad glenoidea.

La fijación rígida en la técnica sagital obliga a situar el cóndilo en «céntrica» y ello no es fácil en un paciente químicamente relajado y en posición de decúbito supino.

La incisión para la OSO, difiere poco de la correspondiente a la de la técnica sagital, aunque algo más prolongada en su extremo superior. Requiere también separadores especiales y es cierto que para la osteotomía a nivel sigmoideo, la visibilidad es algo limitada. Sin embargo, en los casos en que la rama tenga poco grosor, con la técnica sagital hay más peligro de fractura y lesión del paquete vásculo-nervioso al separar los fragmentos.

Con la técnica subcondílea oblicua se evitan estas dos situaciones ya que la delgadez de la rama no es un inconveniente y lesionar el dentario no es posible si la línea de osteotomía pasa por detrás de su entrada en la rama. reached the posterior mandibular border from the signoid notch-presented two disadvantages in our opinion: certain difficult to evade the entry of the v.m. package in some cases and also the fragment was very narrow in its inferior end and could cause a distal necrosis. The horizontal line of our osteotomy eliminates both things.

\section{Discussion}

Before having the data that the theses mentioned gave us, we believed that the SOO was more beneficial for the TMJ than the sagittal technique, as it permitted freedom to the condyle to adopt the most adequate «comfortable» position within the articular cavity.

There is another very interesting fact that supports the choice of the SOO and it is that the consideration of the facture callus does not end until after at least three months. This means that during a long post-operative period, the callus is "soft» and "malleable» to a certain degree. This favors the fact that the condyle adopts the most comfortable relationship with the glenoid cavity. Rigid fixation in the sagittal technique makes it necessary to place the condyle in «centric» position and this is not easy in a chemically relaxed 
Desde hace tiempo que nosotros no mantenemos un bloqueo intermaxilar de 40 días. Realizamos un bloqueo elástico en el quirófano y a los 10 ó 12 días comenzamos con una apertura que permita una alimentación muy blanda.

Posteriormente, se retiran los elásticos para comer y se mantienen con poca tensión día y noche. Con ello se va a «dirigir» y facilitar la acomodación condílea paulatinamente.

El criterio es similar al seguido en las fracturas del cóndilo. En ellas también se instaura una movilización precoz dirigida,

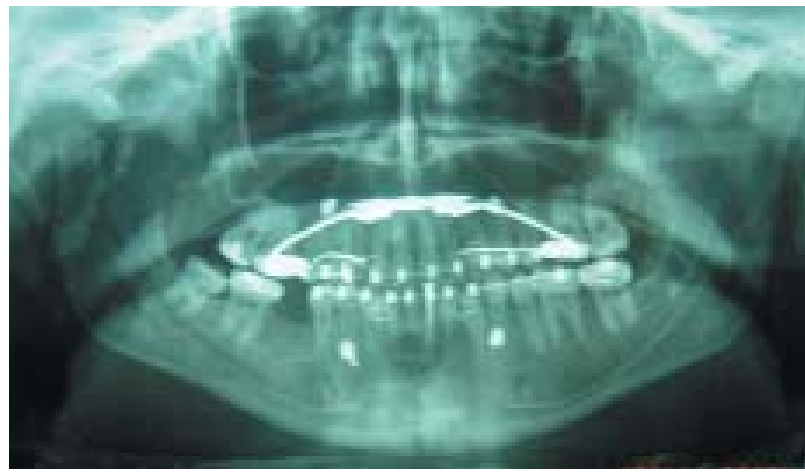

Figura 5. Panorámica postoperatoria. Figure 5. M.R.I. Postoperatory control. patients and in the supine decubitus position.

The incision for the SOO differs little from that corresponding to that of the sagittal technique, although it is somewhat more prolonged in its superior end. It also requires special retractors and it is true that the visibility is somewhat limited for the sigmoid osteotomy. However, in the cases in which the ramus has little thickness, there is dancon objeto de mantener la simetría.

El peligro de recidiva en la OSO es menor al no haber obligado al cóndilo adoptar una posición forzada y así lo hemos comprobado en nuestros casos. Los defensores de la técnica de Obwegeser mantienen como ventaja importante el hecho de que el paciente no precise bloqueo intermaxilar en el postoperatorio. Teóricamente es así, pero la realidad es que durante ocho o diez días existe limitación de apertura.

De cualquier forma ¿la posibilidad de abrir la boca precozmente es más deseable que conseguir equilibrio en la ATM?

En las osteotomías combinadas -maxilar superior y mandíbula- también hemos encontrado ventajas con la OSO, comprobando una favorable reubicación de los cóndilos y ausencia de patología articular.

\section{Ventajas de la osteotomia subcondilea oblícua (OSO)}

A. La técnica es relativamente más fácil, si se consigue un buen campo quirúrgico

B. Es una intervención más rápida (45-50 minutos cada lado).

C. No precisa osteosíntesis alguna.

D. El fragmento condilar queda libre y sobre la cara externa de la rama.

E. No es preciso conseguir la posición céntrica del cóndilo.

F. El bloqueo intermaxilar sólo se mantiene 10 ó 12 días.

\section{Conclusión}

Nosotros consideramos que la técnica de OSO es la más adecuada para el tratamiento del prognatismo por reunir ventajas estéticas y funcionales y minimizar las recidivas.

Hoy día distintas escuelas en el mundo participan de esta opinión.

Desde el principio nos hemos referido al tratamiento quirúrgico del prognatismo, no del retrognatismo.

No cabe duda que en estos casos la OSO no está indicada y hay que recurrir a la osteotomía sagital, L invertida, distracción, etc.

\section{Bibliografía}

1. Obwegeser HL. The indications for surgical correction of mandibular deformity by the sagittal splitting technique. Br J Oral Surg 1963;1:157. ger of fracture and injury of the vascular-nervous package with the sagittal technique when separating the fragments. With the subcondylar oblique technique, these two situations are avoided since the thinness of the ramus is not a disadvantage and it is not possible to injure the teeth if the osteotomy line passes behind its entry in the ramus. We have not maintained an intermaxillary fixation of 40 days for some time. We perform an elastic fixation in the surgery room and begin with an opening at 10 or 12 days that makes a very soft diet possible. After, the elastic fixation are removed to eat and to maintain little tension day and night. With it, the condyle accommodation will be slowly directed and facilitated. The criterion is similar to that followed in condyle fractures. In them, an early directed mobilization is also established to maintain symmetry.

The danger of relapse in the $\mathrm{SOO}$ is less when the condyle is not required to adopt a forced position and we have verified this in our cases. The defenders of the Osbwegeser technique maintain the important advantage of the fact that the patient does not require intermaxillary fixation in the postoperative period. Theoretically this is true, however the truth is that there is opening limitation for eight or ten days. In any event, is the possibility of opening the mouth early more desirable than achieving a balance in the TMJ? In the combined osteotomies -upper maxillary and mandible- we have also found advantages with the SOO, verifying a favorable relocation of the condyles and absence of articular pathology.

\section{Advantages of subcondylar oblique osteotomy (SOO)}

A. The technique is relatively easier, if a good surgical field is achieved.

B. It is a faster operation (45-50 minutes each side).

C. It does not require any osteosynthesis.

D. The condylar fragment remains free and on the external ramus face.

E. It is not necessary to achieve the centric position of the condyle. 
2. Hinds EC. Surgical correction of mandibular deformities. Am / Orthodont 1957;43:171-3.

3. Caldwell JB, Letterman GS. Vertical osteotomy in the mandibular rami for the correction of prognathism. Oral Surg 1954;12:185-202.

4. Monje F. Influencia de los factores extra articulares sobre la ATM Estudio experimental en ratas. Tesis doctoral. L. 992.

5. Fernández Sanromán J. Influencia de la cirugía ortognática en la articulación temporomandibular. Estudio prospectivo clínico y por imagen. Tesis doctoral 1995.

6. Alonso del Hoyo J. Plan de tratamiento ortodóncico-quirúrgico en las deformidades maxilofaciales. XVI Congreso de la SEDO. Palma de Mallorca. Junio 1980.
F. The intermaxillary fixation is only maintained 10 or 12 days.

\section{Conclusions}

We consider that the SOO is the most adequate for the treatment of prognathism to gather esthetic and functional advantages and minimize relapses.

Nowadays, different schools in the world share this opinion. From the onset, we have referred to surgical treatment of prognathism, not retrognathism.

There is no doubt that in these cases, the $\mathrm{SOO}$ is not indicated and the sagittal osteotomy, inverted L, distraction, etc., must be used. 